\title{
上顎エナメル上皮腫の臨床統計的観察
}

\author{
森田章介・有家 巧・上月 清・中嶋正博 \\ 堀井活子・野阪泰弘・角熊雅彦・廣田克征 \\ 赤根昌 樹・岡野博 郎
}

\section{A clinicostatistical study of ameloblastomas of the maxilla}

\author{
Shosuke Morita - Takumi Arika - Kiyoshi Jogetsu - Masahiro Nakajima \\ Katsuko Hori • Yasuhiro Nosaka • Masayuki Tsunokuma • Katsuyuki Hirota \\ Masaki Akane • Hakuro Okano
}

\begin{abstract}
We analyzed 10 maxillary ameloblastomas clinicostatistically for the past 23 years from 1970 to 1992 . The incidence of maxillary ameloblastoma was $6.5 \%$ of all ameloblastomas in the jaw bones. Age at the initial visit was the fifth decade or over in eight patients. Many tumors extended from the anterior or premolar to molar region and 6 cases involved the maxillary antrum. There was no case with an embedded tooth in the tumor. Radiographically, unilocular and multilocular radiolucency was seen in the majority of cases. Histologically, follicular type was seen in six cases, basal cell ameloblastoma in 3, and desmoplastic ameloblastoma in 1. Two cases of follicular type and 1 of basal cell ameloblastoma were malignant ameloblastomas. Recurrence was noted in 2 of the cases; both of these 2 cases were malignant ameloblastomas.
\end{abstract}

Key words: ameloblastoma (エナィル上皮腫), maxilla (上顎), clinicostatistics（臨休統計）

\section{緒}

\section{言}

上顎のエナメル上皮腫の発生頻度は, 本邦では下顎に 比べて著しく低い。このため上顎エナメル上皮腫の多数 例での検討はほとんどみられない，そこで今回当科での 10例について臨床統計的観察を行ったので報告する.

\section{対 象}

1970年から1992年までの 23 年間に当科で組織学的にェ ナメル上皮腫と診断された上㴿症例10例を対象とした. 症例の内訳は 1 次症例 9 例, 再発症例 1 例であった。

\section{研 究 方 法}

\section{1. 臨床的観察}

1）上靧症例の発生頻度，2）初診時年龄および性

大阪歯科大学口腔外科学第 2 講座

(主任：岡野博郎教授)

Second Department of Oral and Maxillofacial

Surgery, Osaka Dental University (Chief: Prof.

Hakuro Okano)

受付日：平成 5 年 4 月 12 日
別，3）主訴，4）発現部位，5）臨床診断。

\section{2. $\mathbf{X}$ 線学的観察}

1) 骨吸収像の分類，2）上顎洞および上顎骨後壁へ の拡大，3）埋伏歯の有無，4）歯根の吸収状態：4症

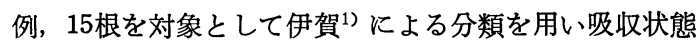
を検討した。

\section{3. 組織学的観察}

1) WHO 分類 ${ }^{2)}$ による組織型, 2 ) 組織型と発現部 位，3）組織型とX線像，4）悪性エナメル上皮腫.

4. 治療法と予後

結

果

\section{1. 臨床的観察}

1) 発生頻度

対象期間の下顎症例は 143 例であり, 全エナメル上皮 尰に和ける上顎症例の発生頻度は $6.5 \%$ であった。

2 ）初診時年齢扣よび性別

11〜80歳で， 60 代が 3 例で最も多く，40および50代と つづき, 平均 50.8 歳であった（表）. 珄別は男 6 名, 女 4 名であった.

3) 主 訴 
表 上顎エナメル上皮腫症例一覧

\begin{tabular}{|c|c|c|c|c|c|c|c|c|}
\hline 症例 & 年歯 & 性 & 部 位 & 主 訴 & 臨床診断 & $\mathrm{X}$ 線像 & 組 織 型 & 治 療 \\
\hline 1 & 11 & 男 & 7〜C| (洞) & $\begin{array}{l}\mathrm{E} \mid \text { 抜歯窩 } \\
\text { 治癒不全 }\end{array}$ & 良 性 腫 瘍 & 単房性 & 㴓胞型（栜細胞腫型） & 摘出搔爬 \\
\hline 2 & 34 & 男 & 5 1 (洞) & 治|癒歯窝 & 良 性 腫 瘍 & 多房性 & 潇胞型（棘細胞腫型） & 摘出搔爬 \\
\hline 3 & 41 & 男 & $1 \sim 4$ & 歯肉腫脹 & 良性 腫 瘍 & 蜂巣状 & Desmoplastic Ameloblastoma & 部分切除 \\
\hline 4 & 46 & 女 & 7〜3 (洞) & 5| 部 疼 痛 & 慢性, 骨髅炎 & 硬化状 & $\begin{array}{l}\text { 基底細胞エナメル上皮腫 } \\
\text { (悪性エナメル上皮腫) }\end{array}$ & 片側切除 \\
\hline 5 & 51 & 女 & $8 \sim 4$ & 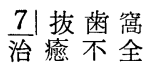 & 良性腫瘍 & 単房性 & $\begin{array}{l}\text { 潈胞型 } \\
\text { (徳性エナメル上皮腫) }\end{array}$ & 部分切除 \\
\hline * 6 & 51 & 女 & $3 \sim 8$ (洞) & 歯肉腫脹 & 良性腫瘍 & 多房性 & 基底細胞エナメル上皮腫 & （転院） \\
\hline 7 & 61 & 男 & $\underline{2 \sim 6}$ & 歯肉腫脹 & 良性腫瘍 & 単房性 & 基底細胞エナメル上皮腫 & 摘出搔爬 \\
\hline 8 & 65 & 男 & $8 \sim 1 \mid$ (洞) & 歯肉腫脹 & 良性腫瘍 & 多房性 & 㴧胞型（棘細胞腫型） & （転院） \\
\hline 9 & 68 & 女 & $8 \sim 5 \mid$ (洞) & 6 1 部疼痛 & 悪性 腫 瘍 & 単房性 & 潓胞型 & 部分切除 \\
\hline 10 & 80 & 男 & $8 \sim 4$ (洞) & 煩部腫脹 & 悪性 腫 瘍 & 多房性 & $\begin{array}{l}\text { 濾胞型 } \\
\text { (悪性エナメル上皮腫) }\end{array}$ & (手術拒否) \\
\hline
\end{tabular}

(洞)：上顎洞八払大 $*$ : 再発症例

歯肉または煩部腫脹が 5 例, 抜歯窩の治癒不全 3 例, そして疼痛 2 例であった。

4 ) 発現部位

前歯から大臼歯部が 5 例で最も多く，次いで臼歯部 3 例, 前歯から小臼歯部 2 例であった。

\section{5 ) 臨床診断}

良性腫瘍が 7 例, 悪性腫瘍が 2 例, 慢性骨䯣炎が 1 例 であった

\section{2. $\mathbf{X}$ 線学的観察}

\section{1) 骨吸収像の分類}

単房性と多房性が各 4 例, 蜂巣状および骨硬化像を示 したものが各 1 例であった。

\section{2）上顎洞および上顎骨後壁への拡大}

腫瘍が上顎洞に扗大していたもの 6 例，また上顎骨後 壁が破壊されていたもの 3 例であった。

3 ）埋伏歯の有無

腫瘍内に埋伏歯を認めた症例はなかった。

\section{4) 歯根の吸収状態}

Type A および D が各 7 根, Type C が 1 根であっ た。な症例別にみると，2例ではほとんどが Type A で，他の 2 例ではすべて Type D であった。

\section{3. 組織学的観察}

\section{1) 組織型}

濾胞型 6 例（良性型 4 例，悪性型 2 例)，基底細胞工 ナメル上皮腫 3 例（良性型 2 例, 悪性型 1 例）扣よび Desmoplastic Ameloblastoma (以下 DA と略す) 1 例 で，悪性エナメル上皮腫が 3 例認められた。な和濾胞型 の良性型 4 例のらち 3 例沶よび DA は細胞亜型として は棘細胞腫型に分類されるものであった。

2 ) 組織型と発現部位
DA および濾胞型の症例 2 はほぼ前歯部に限局し, 濾 胞型の症例 8 は右側上顎全体に及んでいた。なお，これ ら 2 例の濾胞型は棘細胞腫型を示していた。 その他の症 例は主に臼歯部に発現していた。

\section{3 ）組織型とX線像}

DA は蜂巣状を示し, 症侧 4 の悪性エナメル上皮腫は 骨形成を伴っていたため硬化状を呈していた．その他で は組織型とX線像との間に相関はみられなかった。

4 ）悪性エナメル上皮腫

症例 $5^{3)}, 10$ では腫瘍胞巣は濾胞状を示し，前者は多 発性の肺転移を生じていた，症例 $4^{4)}$ は基底細胞エナメ ル上皮腫の悪性型で, 腫瘍内部に著明な骨新生がみられ た。

\section{4. 治療法と予後}

転院および手術拒否などのため，手術を行った症例は 良性型 5 例と悪性型 2 例の計 7 例であった。手術法の内 訳は良性型に対しては摘出搔爬 3 例および上顎骨部分切 除 2 例であり, 悪性型に対しては上顎骨片側切除扣よび 部分切除各 1 例であった。再発は 2 例にみられ，いずれ も悪性エナメル上皮腫で， 1 例は肺転移のため死亡，他 の 1 例には再度部分切除を行い経過良好である.

\section{考察}

\section{1. 臨床的事項}

本邦でのエナメル上皮腫における上顎症例の頻度は約 $5 \%$ といわれ，本研究でも $6.5 \%$ であった。 一方欧米で は20\%前後の報告が多く，人種により発生頻度が異なっ ている．初診時年齢は下顎では10～30代に好発するのに 比べ，上顎は年齢が高いと報告され，今回の症例でも 10 代は 1 例のみで，他はすべて 30 代以上であり，平均年齢 
も50.8歳と高かった. 主訴は無痛性腫脹が半数を占め, 拔歯窩の治癒不全の 3 例は腫瘍により歯槽骨が吸収さ れ，動摇を生じたため抜歯されたもので，抜歯窩壁には 易出血性の腫瘍が認められた。疼痛の 2 例では, 1 例は 悪性エナメル上皮腫で腫瘍性の疼痛と思われ, 他の 1 例 は義歯により腫瘍上の粘膜に潰瘍を形成したものであっ た. 発現部位は臼歯部を中心としたものが多数を占め, 前歯から小田歯部のものは 2 例で, 茅野 ${ }^{5)}$ の約半数は前 雪部であったとの報告とは異なっていた。臨床診断の多 くは良性腫瘍であったが，骨骨道炎と診断した 1 例は持続 性の疼痛があり, X線写真で骨硬化像を示した症例であ った. 臨床所見で悪性腫瘍と診断した 2 例はいずれも $\mathrm{X}$ 線写真では吸収像の辺縁が帆立て貝状を示していたこと から,むしろ良性腫瘍と診断すべきであったと思われ た.

\section{2. $\mathbf{X}$ 線像}

Mehlisch $5^{6)}$ は単房性が大多数であったと報告して いるが, 本研究では単房性と多房性が各 4 例と同数で, 蜂巣状のものは 1 例のみであった。 また埋伏歯を含んで いた症例はなく，初診時年龄が下顎に比べ高いことか ら, 腫瘍の発生時期が下顎とは異なるものと思われる. 上顎洞に拡大したり，上顎骨後壁が破壊されていたもの が多数みられ，本腫瘍が臼霜部に発生すると容易に上方 や後方へ拡大することを示している．これは治療法とも 関連し, 画像診断にて正確な腫瘍の範囲を把握しておか ねばならない，歯根吸収は 2 例ではほとんどが著明に吸 収され鋸歯状を示す Type A であったが，他の 2 例で は歯根膜腔や歯槽硬線の消失を示す Type D であり, 症例により吸収状態が異なっていた。

\section{3. 組織像}

上顎エナメル上皮腫は下顎とは異なった組織像を示す といわれ，茅野 ${ }^{5)}$ は I 型, II 型および両者の混在型が72 $\%$, また丹羽ら ${ }^{7)}$ は棘細胞型 7 例, 網状型 2 例, 基底細 胞型 1 例と報告している. 今回の症例でも下顎では少な い棘細胞腫型を示す濾胞型や基底細胞エナメル上皮腫が 6 例, DA 1 例で, さらに滤胞型の 2 例および基底細胞 型の 1 例は覀性エナメル上皮腫であり, 扁平上皮化生を 伴わない定型的な濾胞型は 1 例のみであった。 また石川 分類では I 型 4 例, II 型 5 例と両者で大多数を占めてい た. 茅野5) はこれらの差異について下顎骨との発生学 的, 解剖学的差異を考慮する必要があると述べている. 組織型と発現部位およびX線像との明瞭な相関はみられ なかったが，前歯部にほぼ限局したものはDA と棘細胞 腫型であった。 下顎でも前歯部では棘細胞腫型が多く,
しかも比較的年跲が高いことから，腫痬の発生時期や骨 梁構造などが関与しているものと思われる．悪性エナメ ル上皮腫が 3 例みられたが，対象期間中の下顎症例 143 例では 1 例も認められなかった。

\section{4. 治療法と予後}

上顎エナメル上皮腫は上顎骨の骨皮質が薄いため, 腫 瘍は骨膜に拡大しやすく, また眼窩, 翼口蓋窩, 頭蓋底 に浸潤することがある。このため上方や後方へ進展した ものには健康組織を含めて en bloc に切除する根治的療 法が望ましい.今回再発を生じた 2 例とも悪性エナメル 上皮腫であり,さらに広範囲の切除が必要であった。

\section{結語}

1970～1992年の 23 年間に当講座を受診した上顎エナメ ル上皮腫10例について，臨床統計的観察を行った。

顎骨のエナメル上皮腫に括ける上顎症例の頻度は 6.5 $\%$ で, 初診時年齢は 40 代以上が 8 例あった，発現部位は 前歯から大臼歯部が最も多く，腫瘍が上買洞へ進展して いたものが半数以上を占め, 腫瘍内に埋伏霜を認めた症 例はなかった，X線像は単房性および多房性が多く，蜂 巣状は 1 例のみであった．組織型は濾胞型 6 例, 基底細 胞エナメル上皮腫 3 例, DA 1 例で, 濾胞型の 2 例扣よ び基底細胞エナメル上皮腫の 1 例は悪性エナメル上皮腫 であった．治療法は健康組織を含めた切除が望ましい.

\section{引用 文 献}

1）伊賀成知：顎骨内疾患による歯根吸収に関する 研究. 日口外誌 32: 1121-1138 1986.

2) Kramer, I.R.P., Pindborg, J. J., et al.: Histological Typing of Odontogenic Tumors. 2nd Ed, Springer-Verlag, Berlin 1992.

3）森田章介, 有家 巧, 他 : 肺転移を生じた上顎 覀性エナメル上皮腫。日口外誌 33：1529-1540 1987.

4) 有家 巧, 森田章介, 他: 著明な骨新生を伴っ た上顎覀性エナメル上皮腫の病理組織学的検討. 日口外誌 39: 469-474 1993.

5）茅野照男：エナメル上皮腫の組織由来につい て一特に埋伏歯を伴 万病変との関連から一. 口 病誌 49: 333-357 1982.

6) Mehlisch, D.R., Dahlin, D.C., et al.: Ameloblastoma: a clinicopathologic report. J Oral Surg 30: 9-22 1972.

7) 丹羽大治, 長山 勝, 他 : 上顎エナメル上皮腫 の診断と予後に関する検討. 頭頸部腫瘍 11: 3251984. 